\author{
Asian Journal of \\ Medical and Biological Research \\ ISSN 2411-4472 (Print) 2412-5571 (Online) \\ www.ebupress.com/journal/ajmbr
}

\title{
Article \\ Growth response of Aspergillus flavus IMS1103 isolated from poultry feed
}

Monzur Morshed Ahmed*, Md. Fakruddin, Md. Nur Hossain, Khandaker Rayhan Mahbub and Abhijit Chowdhury

Industrial Microbiology Laboratory, Institute of Food Science \& Technology (IFST), Bangladesh Council of Scientific \& Industrial Research (BCSIR), Dhaka, Bangladesh

*Corresponding author: Monzur Morshed Ahmed, Industrial Microbiology Laboratory, Institute of Food Science \& Technology (IFST), Bangladesh Council of Scientific \& Industrial Research (BCSIR), Dhaka, Bangladesh. E-mail: monjur_28@yahoo.com

Received: 7 June 2016/Accepted: 20 June 2016/ Published: 30 June 2016

\begin{abstract}
Aspergillus flavus strains were isolated from locally available poultry feeds. Effect of temperature, $\mathrm{pH}$ and culture media on growth of Aspergillus flavus was studied. Temperature ranged from $4-42^{\circ} \mathrm{C}(4,10,20$, $25,30,37$ and $42^{\circ} \mathrm{C}$ ) was examined. Except for $4^{\circ} \mathrm{C}$ and $10^{\circ} \mathrm{C}$, the isolate was able to grow for the whole temperature range. The growth was maximum at $25^{\circ} \mathrm{C}$ and was influenced with increasing or decreasing of temperature from $42^{\circ} \mathrm{C}$ to $20^{\circ} \mathrm{C}$. The lag time was strongly influenced by the temperature at lower temperature level than at higher temperature range. Effect of $\mathrm{pH}$ on growth of Aspergillus flavus was also examined; from comparison of 3 different $\mathrm{pH}$ levels, it is concluded that at most temperatures $\mathrm{pH} 6.5$ showed a higher growth rate and as a consequence required a shorter time to achieve maximum colony diameter. No significant variations in the lag time were observed. A natural poultry feed meal agar medium (FMAM) was developed in the laboratory and growth of A. flavus was compared with other 2 synthetic dehydrated media namely; Czapek'sdox Agar (CDA) and potato dextrose Agar (PDA). Poultry feed meal agar medium showed better growth response than Czapek'sdox agar and potato dextrose agar at all conditions. At $25^{\circ} \mathrm{C}$ and $\mathrm{pH} 6.5$ found optimum for growth of Aspergillus flavus in feed meal agar medium whereas, temperature $30^{\circ} \mathrm{C}$ and $\mathrm{pH} 6.5$ found optimum for growth for Czapek'sdox agar media and temperature $30^{\circ} \mathrm{C}$ and $\mathrm{pH} 6$ showed high growth rate on potato dextrose agar. Poultry feed meal media showed high affinity for growth of mycelium and early spore formation than other media examined.
\end{abstract}

Keywords: Aspergillus; growth; response; temperature; $\mathrm{pH}$

\section{Introduction}

Food and feed usually become contaminated and spoiled by moulds during their production and especially during storage. Moulds are particular concern to the food industry as spoilage organism and also as potential mycotoxin producers (Spadaro et al., 2010). In recent time, feed stuffs are also contaminated by mould growths and especially presences of aflatoxins are reported frequently in poultry and fish feeds. For this reason, it is important to understand the growth characteristics and kinetics of these organisms at various environmental conditions and influences of extrinsic and intrinsic factors on their growth (Rosso and Robinson, 2001).Food losses resulting from occurrences of moulds are worldwide economic problem. The Food and Agriculture Organization (FAO) of the United Nations estimated that due to mould infection approximately $25 \%$ of all food production worldwide is lost after harvesting (Zeinab et al., 1992).

Aspergillus flavus is an asexual filamentous fungus having agronomic and health importance. Under favorable environmental conditions, drought stress and high temperature, it can infect multiple crops, such as peanut, tree nut, corn and cotton (Payne, 1998). Aspergillus flavus is a potential aflatoxin producer and infect some crops at field level and also grows at post-harvest conditions. Aflatoxin is reported to carcinogenic and toxic both to human and animals (Bennett and Klich, 2003). Surveillance and/or control of aflatoxin contamination are 
increasingly important and have been reported throughout the tropical and subtropical regions (Arim, 1995). Aflatoxin research in Philippines began with an aflatoxin survey of various foods in 1967. Uganda is an Eastern African country with tropical climate and was one of the countries where aflatoxin studies first started (Kaaya and Warren, 2005). Many previous studies have showed influence of environmental factors on production of aflatoxin by Aspergillus flavus (Northolt et al., 1977; Trucksess et al., 1988; Aldred et al., 1999; Astoreca et al., 2007; Giorni et al., 2008; Mehra and Jaitly, 1995). Mousa et al. (2013) stated that temperature is the most important factor in the physical environment affecting metabolic activities of the fungi.

Major objectives of the present study were to investigate the effect of different temperatures and $\mathrm{pH}$ on growth of Aspergillus flavus isolates, isolated from poultry feeds from different feed producer's stores. The study was sequenced in three main parts. Firstly, the effect of temperatures on the growth was studied at different temperature namely $4,20,25,30,37$ and $42^{\circ} \mathrm{C}$. To observe variation of growth kinetics, three different media; potato dextrose agar (PDA), Czapek'sdox agar and feed meal agar (FMA) and various level of pH e.g. 6.0, 6.5 and 7.0 were examined. The results are discussed in details in the results and discussions part of this thesis. A general conclusion is drawn on the basis of the results obtained.

\section{Materials and Methods}

\subsection{Sample collection}

15 poultry feed samples were collected from different farms and shops. Feed samples were collected during a 6 months-long period from December 2009 to May 2010. Samples were collected aseptically following standard microbiological protocol and transported to the laboratory as soon as possible.

\subsection{Isolation of Aspergillus spp.}

Dilute plate technique was used for isolation of fungi from the samples according to Pratiwi et al. (2015). A part of feed sample weighing $20 \mathrm{~g}$ was mixed with $180 \mathrm{ml}$ of saline solution $(0.85 \%$ sodium chloride) on a horizontal shaker for ca. 30 minutes. Then, $1 \mathrm{ml}$ of appropriate dilutions made up to 10-5 was applied on Potato Dextrose Agar for Aspergillus flavus. After 5-7 days of incubation at $25^{\circ} \mathrm{C}$ in dark presumptive colonies were selected and transferred onto appropriate identification media.

\subsection{Identification of Aspergillus spp.}

Colony morphology of fungi in different artificial media alone can give a preliminary idea about identification of most fungal strains (Klich, 2002). Conidial suspensions of isolated Aspergillus spp. was inoculated on the Czapek's-dox- agar (CYA), Potato Dextrose agar (PDA) and Feed meal agar media (FMAM) for observation of colony characteristics and incubated in the dark at $25^{\circ} \mathrm{C}$ for $7-14$ days. Species identification was carried out according to Balajee et al. (2007). The development of the colony over a period was observed considering the texture, size and color of the colony, sporulation and reverse color. Identification also includes microscopic observation of the presumptive Aspergillus spp.

\subsection{Assessment of hyphal growth rate}

The radial mycelial growth of each plate was measured in two directions at right angles to each other. Measurements were recorded on alternate days during the growth until the Petri plates were completely colonized. This was measurements by digital slide carlipus. Radial mycelial growth vs. time was plotted and radial growth rates were evaluated from the slopes by linear regression (Baxter et al. 1998; Aldred et al. 1999).The growth rate $(\mu)$ was expressed as the increase in colony radial growth per unit of time.

\subsection{Specific growth rate determination}

Maximum specific growth rate was determined from the growth curve of Aspergillus flavus at different temperature and different $\mathrm{pH}$ (Guinea et al., 2005).

\subsection{Aflatoxin production assay}

Colony margins together with adjacent surrounding zones were scraped into large test tube $(32 \times 200 \mathrm{~mm})$ containing $10 \mathrm{ml}$ chloroform: acetone $(85: 15 \mathrm{v} / \mathrm{v})$. The suspension was incubated at room temperature $\left(25^{\circ} \mathrm{C}\right)$ for 15 - $20 \mathrm{~min}$ and agitated every $5 \mathrm{~min}$ using a vortex stirrer. The extract was filtered through Whatman no. 1 filter paper and the filtrate evaporated to dryness under $40^{\circ} \mathrm{C}$ in an air circulated oven dryer. The residue was resuspended in $500 \mu \mathrm{l}$ of methanol and aseptically filtered using a $0.2 \mu \mathrm{m}$ syringe filter. It was kept at $4^{\circ} \mathrm{C}$ before been used for analysis by HPLC (Yazdani et al., 2010). 
3. Results

\subsection{Isolation of A. flavus from poultry feed samples}

Poultry feed samples were collected from different areas around Dhaka city. Sample was first pre-enriched in the potato dextrose broth for 24 hours at $25^{\circ} \mathrm{C}$. Enriched cultures were then inoculated on potato dextrose agar plates for colony development. Plates were incubated at $25^{\circ} \mathrm{C}$ for $5-6$ days. Based on morphological characteristics and microscopic observation, spores from suspected colonies were further inoculated on selective media for confirmation of A. flavus and confirmed according to Rath (2001).

\subsection{Growth on potato dextrose agar (PDA)}

Colonies on PDA at $25^{\circ} \mathrm{C}$ is olive to lime-green in color with whitish pigmentation (Figure 1). Texture is woolly, granular presentation. Sclerotia found dark brown to black. Pale brown to cream color pigmentation were present in some isolates. Effuse, lime-green colonies with rough conidiophores and smooth to slightly rough conidia distinguish $A$. flavus isolates.

\subsection{Growth on Czapek'sdox agar (CDA)}

Colonies on Czapek'sdox agar were granular, flat, often with radial grooves, yellow at beginning of growth but becoming bright to dark yellow-green with age (Figure 2). Conidial heads are typically radiate, mostly 300-400 $\mu \mathrm{m}$ in diameter, later splitting to form loose columns, bi-seriate but having some heads with phialides borne directly on the vesicle. Conidiophores are hyaline and coarsely roughened, the roughness often being more noticeable near the vesicle. Conidia are globose to sub-globose in shape (3-6 $\mu \mathrm{m}$ in diameter) and pale-green in color.

\subsection{Microscopic observation}

After observed the microscopic slide, conidiophores were heavy walled, uncolored, coarsely roughened, usually less than $1 \mathrm{~mm}$ in length. Vesicles were elongate. Phialides was uniseriate or biseriate. Conidia was typically round, globose to sub - globose, with smooth to finely roughened walls, appear in chains, and with diameter size of $3-6 \mu \mathrm{m}$. Conidial heads was mostly radiate with conidial masses splitting into blocky columns. Hyphae were septate, pellicle formations were also observed. The distinct colonies were stained on a slide using Lactophenol cotton blue (Figure 3).

\subsection{Influence of temperature on growth of Aspergillus flavus IMS1103}

The growth curves based on colony diameters are characterized by a lag phase followed by a period of linear growth. In the beginning of the growth, formation of white mycelium starts at the place of inoculation and this measurement corresponds with the first measurement point in the growth curve. At temperature $4{ }^{\circ} \mathrm{C}$ and $10^{\circ} \mathrm{C}$ no growth was observed on FMAM (Figure 4). For all other temperatures $\left(20,25,30,37\right.$ and $42^{\circ} \mathrm{C}$ ) the A. flavus isolate starts sporulation with light brown to pale-green spores and mycelium growth successively extended in atypical radial way.

In potato dextrose agar, at temperature $4^{\circ} \mathrm{C}, 10^{\circ} \mathrm{C}$ and $42^{\circ} \mathrm{C}$ no growth was observed (Figure 5). For all other temperatures $\left(20,25,30,37^{\circ} \mathrm{C}\right)$, the A. flavus isolate starts sporulation with olive to lime green spores and different mycelium growth was observed.

In Czapek'sdox agar media, no growth was observed at temperature $4{ }^{\circ} \mathrm{C}, 10^{\circ} \mathrm{C}$ and $42^{\circ} \mathrm{C}$ (Figure 6). Rest of the temperature $(20,25,30$ and 37$){ }^{\circ} \mathrm{C}$ the A. flavus isolate starts sporulation with yellow to dark yellow green spores.

\subsection{Influence of $\mathrm{pH}$ on growth of $A$. flavus}

To determine the influence of $\mathrm{pH}, 3$ different level of $\mathrm{pH}(6.0,6.5$ and 7.0) were examined. At temperature $25^{\circ} \mathrm{C}, \mathrm{pH} 6.5$ showed maximum growth rate and shortest time to reach maximum colony diameter. For $\mathrm{pH} 6.0$ \& 7.0 the growth rate was almost similar but colony diameter was smaller for 7.0 and growth retarded earlier than 6.0 (Figure 7).

At temperature $30^{\circ} \mathrm{C}, \mathrm{pH} 6.5$ showed maximum growth rate for A. flavus isolate but at $\mathrm{pH} 6$ the fungus also showed very close growth performance that indicating the optimum $\mathrm{pH}$ for the growth of the fungus is between and around 6 and 6.5 (Figures 8 and 9).

At temperature $30^{\circ} \mathrm{C}$, pH 6 showed maximum growth rate for A. flavus isolate on potato dextrose agar media, but at $\mathrm{pH} 6.5$ the fungus also showed very close growth performance that indicating the optimum $\mathrm{pH}$ for the growth of the fungus is between and around 6 and 6.5. 
Table1. Growth features of $\boldsymbol{A}$. flavus on potato dextrose agar \& Czapek'sdox agar plates.

\begin{tabular}{|c|c|c|c|}
\hline Media & Color & Conidiophores & Conidia \\
\hline $\begin{array}{l}\text { Potato } \\
\text { dextrose agar }\end{array}$ & $\begin{array}{l}\text { Olive to lime-green in colour with } \\
\text { whitish pigmentation. }\end{array}$ & $\begin{array}{l}\text { Effuse and rough } \\
\text { conidiophores. }\end{array}$ & $\begin{array}{l}\text { Smooth to very finely roughed } \\
\text { conidia }\end{array}$ \\
\hline $\begin{array}{l}\text { Czapek'sdox } \\
\text { agar }\end{array}$ & $\begin{array}{l}\text { Yellow at first but quickly } \\
\text { becoming bright to dark yellow- } \\
\text { green with age. }\end{array}$ & $\begin{array}{l}\text { Conidiophores are hyaline } \\
\text { and coarsely roughened, the } \\
\text { roughness often being more } \\
\text { noticeable near the vesicle. }\end{array}$ & $\begin{array}{l}\text { Conidia are globose to sub- } \\
\text { globose in shape }(3-6 \mu \mathrm{m} \text { in } \\
\text { diameter) and pale-green in } \\
\text { colour. }\end{array}$ \\
\hline
\end{tabular}

Table 2. Microscopic observation of A. flavus isolates.

\begin{tabular}{lllllll}
\hline Size & Stipes Color & Surface & Vesicle Serration & Metula covering & Shape & Conidia Surface \\
\hline $400-800$ & $\begin{array}{l}\text { Pale brown } \\
\text { roughened }\end{array}$ & $\begin{array}{l}\text { Quietly } \\
\text { spherical }\end{array}$ & Biseriate & 314 & $\begin{array}{l}\text { Glubose } \\
\text { ellipsoid }\end{array}$ & $\begin{array}{l}\text { Smooth } \\
\text { roughened }\end{array}$ \\
\hline
\end{tabular}

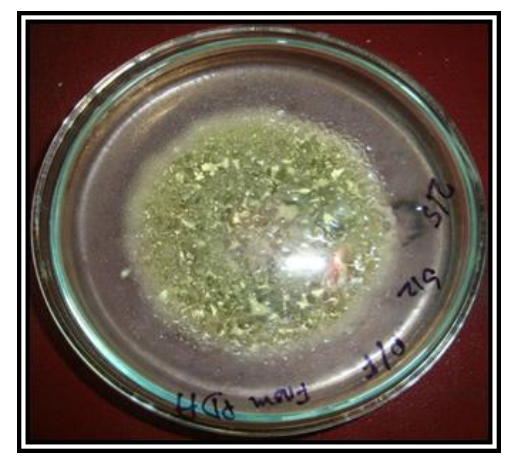

Figure 1. 4 day growth of $A$. flavus IMS1103 on potato dextrose agar at $30^{\circ} \mathrm{C}$.

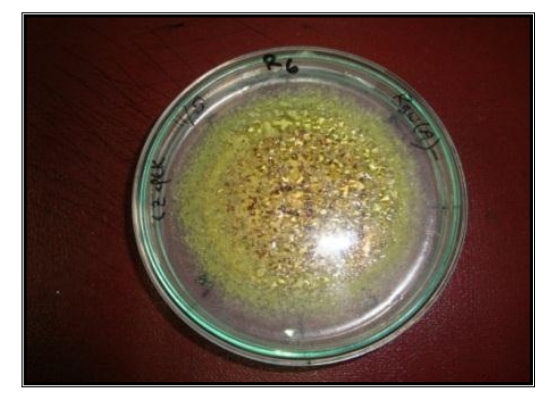

Figure 2. 4 day growth of $A$. flavus IMS1103 on Czapek'sdox agar at $30^{\circ} \mathrm{C}$.

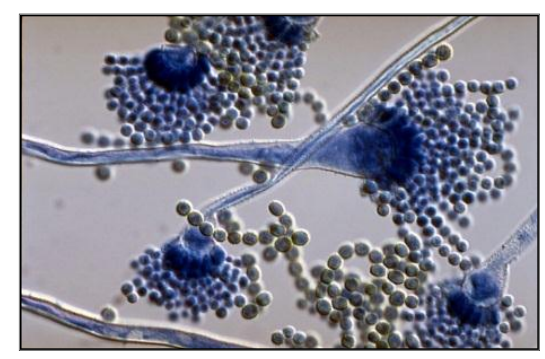

Figure 3. Photograph of isolated Aspergillus flavus strain in the laboratory. 


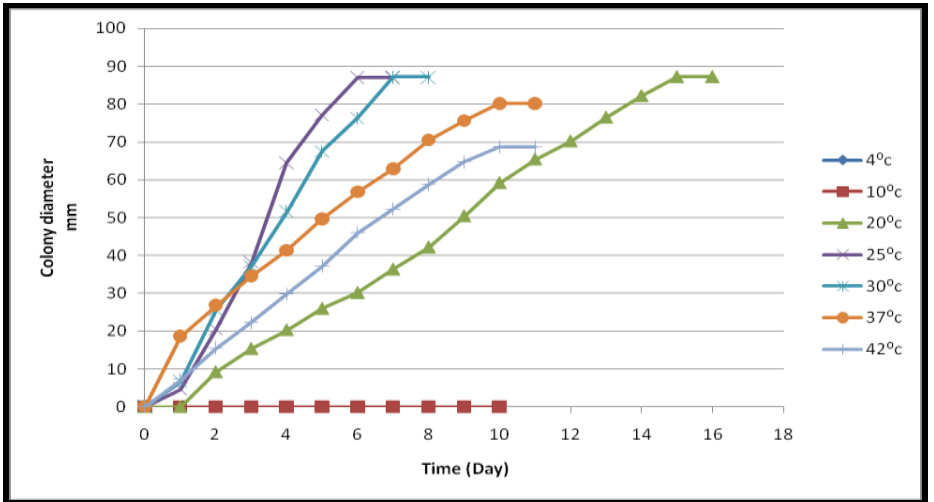

Figure 4. Growth of A. flavus isolate on FMAM at different temperatures.

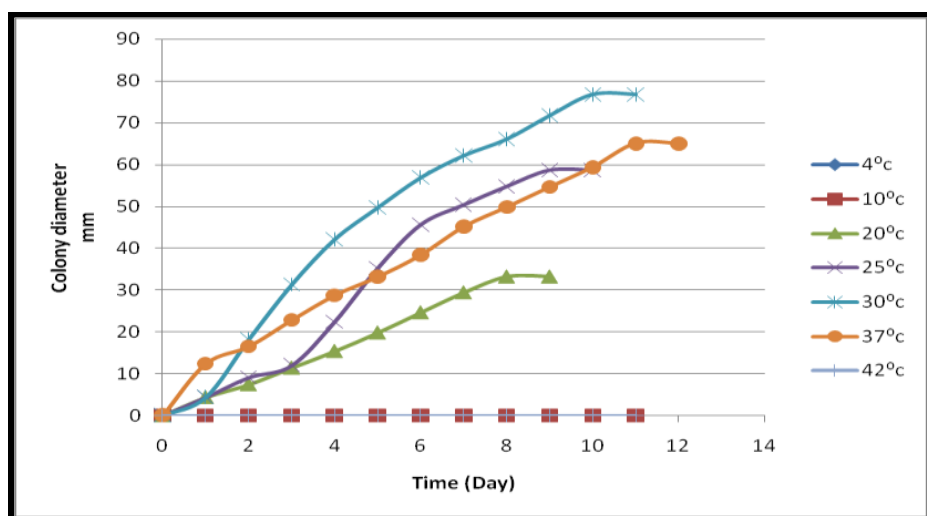

Figure 5. Growth of Aspergillus flavus at the different temperatures onCzapek'sdox agar media.

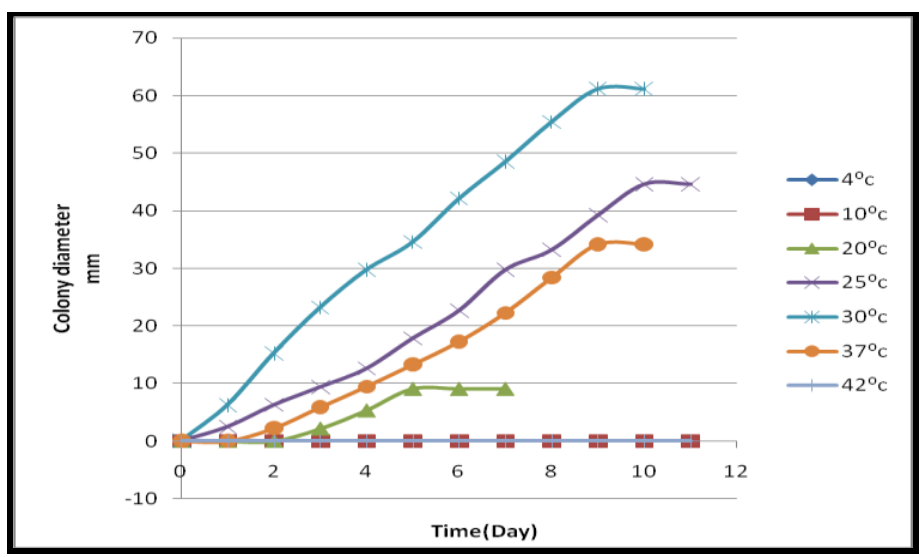

Figure 6. Growth of Aspergillus flavus at the different temperatures on potato dextrose agar media.

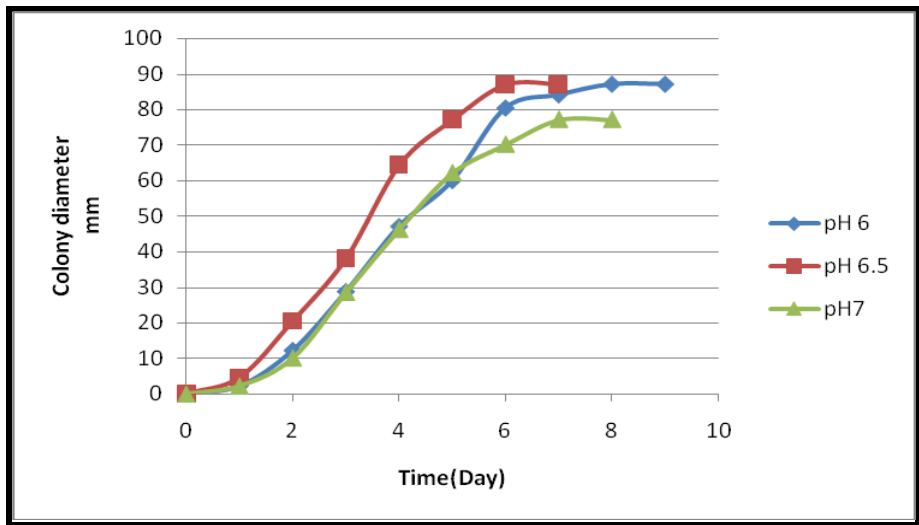

Figure 7. Growth of Aspergillus flavus at temperature $25^{\circ} \mathrm{C}$ for $\mathrm{pH} 6.0,6.5$ and 7.0 on FMAM. 


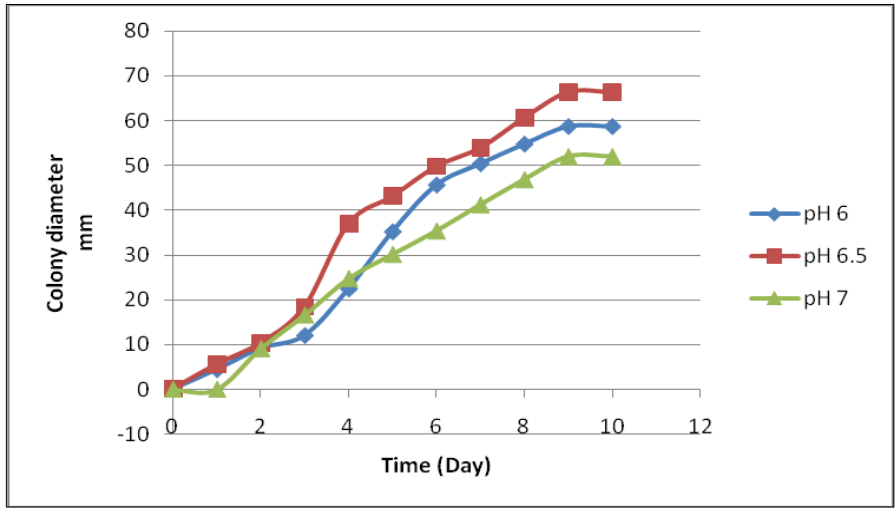

Figure 8. Growth of Aspergillus flavus on temperature $30{ }^{\circ}$ Cat $\mathrm{pH} \quad 6,6.5$ and 7 on Czapek'sdox agar media agar media.

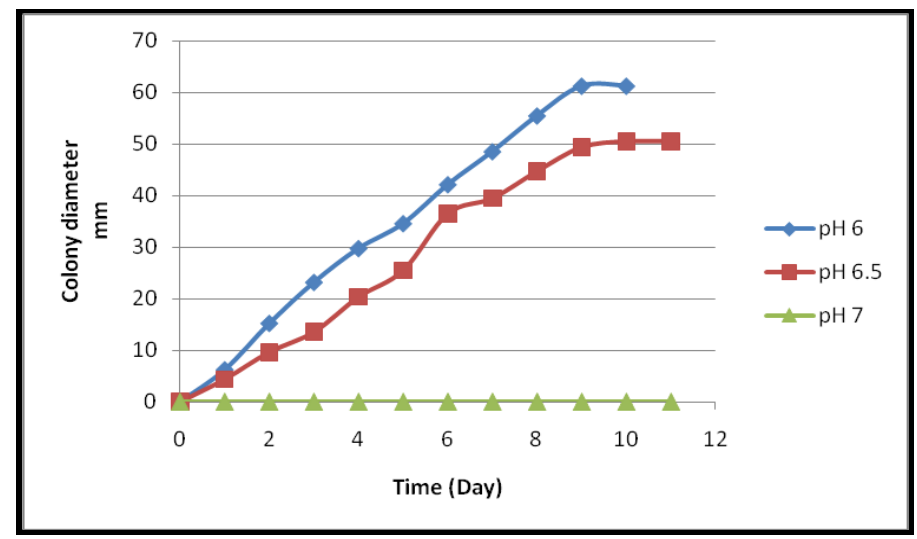

Figure 9. Growth of Aspergillus flavus on temperature $30^{\circ} \mathrm{C}$ at $\mathrm{pH} 6,6.5$ and 7 on potato dextrose agar media.

3.7. Comparisons of three media (Feed meal agar media, Czapek'sdox agar media and potato dextrose agar) on the growth of $A$. flavus

Tables 1 and 2 summarizes comparison of three media for growth of Aspergillus flavus IMS 1103. Feed meal agar media proved to be as suitable as Czapek'sdox agar and potato dextrose agar for growth of Aspergillus.

\subsection{Aflatoxin production}

Aspergillus flavus IMS1103 can produce aflatoxin B1, B2 and G1 but not aflatoxin G2. Feed meal agar media was found more suitable for aflatoxin production by Aspergillus flavus.

\section{Discussion}

The present study was carried out to investigate the effect of extrinsic factors namely temperature and $\mathrm{pH}$ on growth of Aspergillus flavus IMS1103 isolated from poultry feed and to evaluate the performance of a newly developed media (Feed Meal Agar Media) on growth and toxin production of Aspergillus spp.

Temperature showed to have influence on lag time of growth of A. flavus. In case of growth on FMAM, the lag time for $20^{\circ} \mathrm{C}$ was 24 hours while, for $25^{\circ} \mathrm{C}$ it was nearly 18 hours but for other higher temperatures the lag time was 6 to 12 hours. For $25^{\circ} \mathrm{C}$, the time needed to reach the maximum colony diameter was the shortest (6 days) and a decrease or increase temperature resulted in an increase of time to reach the maximum colony diameter. Although $25^{\circ} \mathrm{C}$ showed maximum growth rate for A. flavus isolate but at $30^{\circ} \mathrm{C}$ the fungus also showed very close growth performance that indicating the optimum temperature for growth of the fungus is between and around $25^{\circ} \mathrm{C}$ and $30^{\circ} \mathrm{C}$. At temperature $37^{\circ} \mathrm{C}$, the fungus showed very fast starting of growth and the lag time for the temperature was the shortest among all the temperatures tested. It is also observed that after 24 hours of incubation the growth rate became slower for $37^{\circ} \mathrm{C}$ and time required to reach the maximum colony diameter was 10 days while for $25^{\circ} \mathrm{C}$ it was 6 days. Slower growth rate was also observed at $20^{\circ} \mathrm{C}$ and $42^{\circ} \mathrm{C}$. It grew 
poorly at $42^{\circ} \mathrm{C}$ and highest colony diameter was $68.59 \mathrm{~mm}$ and no more growth occurred after 9 days even the colony diameter was not completed. At $20^{\circ} \mathrm{C}$, the lag time was not influenced compared to other temperatures but showed consistent growth at a slower rate. Based on the results discussed, $25^{\circ} \mathrm{C}$ can be considered as the optimum temperature for growth of the A. flavus strain (Figure 6). In case of growth on Czapek'sdox agar, except temperature $37^{\circ} \mathrm{C}$ the lag time for 20,25 and $30^{\circ} \mathrm{C}$ temperatures was $20-24$ hour but different growth kinetic was observed. At temperature $20^{\circ} \mathrm{C}$ showed consistent growth at a slower rate. This temperature the highest colony diameter was $33.25 \mathrm{~mm}$ and growth ceased after 9 days. Slower growth rate was also observed at temperature $25^{\circ} \mathrm{C}$ and no more growth occurred after 9 days even the colony diameter $(58.78 \mathrm{~mm})$ was not completed. Only temperature $30^{\circ} \mathrm{C}$ showed maximum colony diameter $(76.84 \mathrm{~mm})$ within 10 days in this media. But it was not highest colony diameter $(87 \mathrm{~mm})$, which was observed at temperature $25^{\circ} \mathrm{C}$ on FMAM. At temperature $37^{\circ} \mathrm{C}$ the fungus showed very fast starting of growth and lag time for the temperature was the shortest among all the temperatures tested. But growth rate was slower than the temperature $30^{\circ} \mathrm{C}$ (Figure 5). So the lag time was not influenced the formation of highest colony diameter. From the above results, $30^{\circ} \mathrm{C}$ is the best temperature for the growth of Aspergillus flavus in Czapek'sdox agar media.

In case of growth on PDA, The lag time for $20^{\circ} \mathrm{C}$ was 72 hours while, for $25^{\circ} \mathrm{C}$ and $37{ }^{\circ} \mathrm{C}$ it was nearly 24 hours. Very slow growth kinetic was observed at temperature $20^{\circ} \mathrm{C}$ and highest colony diameter was $9.03 \mathrm{~mm}$ and growth was stopped after 6 days even the colony diameter was not completed. Slower growth rate was also observed at $25^{\circ} \mathrm{C}$ and $37^{\circ} \mathrm{C}$ and very close growth performance were (44.69 $\mathrm{mm}$ and $34.16 \mathrm{~mm}$ respectively) also showed but growth was completely ceased after 9 to 10 days. At temperature $30^{\circ} \mathrm{C}$ the A. flavus showed very fast starting of growth and lag time for the temperature was the shortest among all the temperature tested (Figures 5 and 6). In potato dextrose agar highest colony diameter $(61.24 \mathrm{~mm})$ was observed at the temperature $30^{\circ} \mathrm{C}$ This growth kinetic was so far different from Czapek'sdox Media and feed meal agar media. So from the above results $30^{\circ} \mathrm{C}$ can be considered as the optimum temperature for growth of the A. flavus on the potato dextrose agar media.

On FMAM, lower $\mathrm{pH}(6 \& 6.5)$ showed better growth rate and colony diameter than $\mathrm{pH} 7.0$ (Figure 7). Lag time at all $\mathrm{pH}$ is lower than that on other media (Czapek'sdox and PDA). On Czapek'sdox agar, for pH 7, the lag time was 24 hours, and highest colony diameter was $52 \mathrm{~mm}$ and no more growth occurred after 9 days even the colony diameter was not completed. At $\mathrm{pH} 7$, the lag time was not influenced compared to other $\mathrm{pH}$ but showed consistent growth at a slower rate (Figure 8). Based on the results, $\mathrm{pH} 6.5$ can be considered as the optimum $\mathrm{pH}$ for the growth of Aspergillus flavus on the Czapek'sdox agar. On potato dextrose agar, highest colony diameter showed $61.24 \mathrm{~mm}$ at $\mathrm{pH} 6$ and growth was ceased after 10days. At pH 6.5 maximum colony diameters was $50.49 \mathrm{~mm}$ and no more growth was observed after 11days. No growth was observed at $\mathrm{pH} 7$ (Figure 9). So, temperature $30^{\circ} \mathrm{C}$ and $\mathrm{pH} 6$ was the optimum for the growth of Aspergillus flavus on the potato dextrose agar media.

There was no significant growth of A. flavus at the temperatures of $4^{\circ} \mathrm{C}$ and $10^{\circ} \mathrm{C}$ on the three culture media. The temperatures of $25^{\circ} \mathrm{C}$ and $30^{\circ} \mathrm{C}$ favored fast colony diameter for the growth of A. flavus on the three culture media. On the other hand slower growth was observed at temperatures $37^{\circ} \mathrm{C}$ and $42^{\circ} \mathrm{C}$ on all the culture media. At temperature $25^{\circ} \mathrm{C}$, A. flavus grew better on feed meal agar media while Czapek'sdox agar media and potato dextrose agar, it was $30^{\circ} \mathrm{C}$. At the temperature of $42^{\circ} \mathrm{C}$, A. flavus was significantly inhibited in the Czapek'sdox agar media and potato dextrose agar. These observations may suggest that the feed meal agar media may influence the growth of A. flavus at higher temperature. Furthermore, it was found that the feed meal agar media supported maximum growth rate of A. flavus of the three media tested. PDA and Czapek'sdox agar media showed lower growth kinetic than the feed meal agar media.

The isolate was found to be able to produce 3 types of aflatoxin (aflatoxin B1, B2 and G1). On FMAM and PDA, three types of aflatoxin were produced, but on Czapek'sdox agar, only aflatoxin B1 and G1 was produced. Toxin production was found to be better on FMAM than on other two medias (PDA and Czapek'sdox).

Growth performance and toxin production of Aspergillus flavus on newly developed FMAM media showed to be comparable to PDA and Czapek'sdox agar media. Nutrient components in feed meal agar medium showed to play an important role in triggering mycelial growth and toxin production and this low cost media can be routinely used for growth of Aspergillus flavus.

\section{Conclusions}

This study examined the effect of temperature and $\mathrm{pH}$ on growth of Aspergillus flavus IMS1103 isolated from poultry feed. Data obtained in this study is critical in building up a picture of the key factors which influence growth and sporulation of strains of this important mycotoxigenic species. Poultry feed meal agar media showed 
high affinity for growth of mycelium and early spore formation than other media examined. This low cost media can be used in place of commercial media which are expensive.

\section{Conflict of interest}

None to declare.

\section{References}

Agnihotri VP, 1964. Studies on aspergilli. XVI. Effect of pH, temperature, and carbon and nitrogen interaction. Mycopathol. Mycol. Appl., 24: 305-314.

Aldred D, N Magan and BS Lane, 1999. Influence of water activity and nutrient on growth and production of squalestatin S1 by a Phoma sp. J. Appl. Microbiol., 87: 842-848.

Arim RH, 1995. Present status of the aflatoxin situation in the Phillippines. Food Add. Contamin., 12: 291-296.

Astoreca A, C Magnoli, ML Ramirez, M Combina and A Dalcero, 2007. Water activity and temperature effects on growth of Aspergillus niger, A. awamori and A. carbonarius isolated from different substrates in Argentina. Intl. J. Food Microbiol., 119: 314-318.

Balajee SA, J Houbraken, PE Verweij, S-B Hong, T Yaghuchi, J Varga and RA Samson, 2007. Aspergillus species identification in the clinical setting. Stud. Mycol., 59: 39-46.

Baxter CJ, N Magan, B Lane and HG Wildman, 1998. Influence of water activity and temperature on in vitro growth of surface cultures of Phoma sp. and production of pharmaceutical metabolites, squalestatins S1 and S2. Appl. Microbiol. Biotechnol. 49: 328-332.

Bennett JW and M Klich, 2003. Mycotoxins. Clin. Microbiol. Rev., 16: 497-516.

Cotty PJ, 1989. Virulence and cultural characteristics of two Aspergillus flavus strains pathogenic to cotton. Phytopathol., 79: 808-814.

Giorni P, P Battilaniand N Magan, 2008. Effect of solute, matric potential and temperature on in vitro growth and sporulation of strains from a new population of Aspergillus flavus isolated in Italy. Fungal Ecol., 1: 102106.

Guinea J, T Peláez, L Alcalá and E Bouza, 2005. Evaluation of Czapeck agar and Sabouraud dextrose agar for the culture of airborne Aspergillus conidia. Diag. Microbiol. Infect. Dis., 53: 333-334.

Kaaya AN and $\mathrm{H}$ Warren, 2005. A review of past and present research on aflatoxin in Uganda. Afr. J. Food Agri. Nutr. Dev., 5: 1-18.

Klich MA, 2002. Indentification of common Aspergillus species, CBS, Netherlands.

Mehra S and A Jaitly, 1995. pH and temperature optima for growth and sporulation in some common fungi from city waste. Mycosci., 36: 243-246.

Northolt MD, HP Van Egmond and WE Paulsch, 1977. Differences between A. flavus strains in growth and aflatoxin B 1 production in relation to water activity and temperature. J. Food Prot., 40: 778-781.

Payne GA, 1998. Process of contamination by aflatoxin-producing fungi and their impact on crops. In: Sinha K.K. and Bhatnagers D., editors. Mycotoxins in Agriculture and Food Supply.Marcel Dekker, New York, NY.

Rath PM, 2001. Phenotypic and genotypic characterization of reference strains of the genus Aspergillus. Mycoses, 44: 65-72.

Rosso L and TP Robinson, 2001. A cardinal model to describe the effect of water activity on the growth of moulds. Intl. J. Food Microbiol., 47: 141-146.

Spadaro D, S Patharajan, A Lore, Ml Gullino and A Garibaldi, 2010. Effect of pH, water activity and temperature on the growth and accumulation of ochratoxin A produced by three strains of Aspergillus carbonarius isolated from Italian vineyards. Phytopathol. Mediterr., 49: 65-73

Trucksess M, L Stoloff and P Mislivec, 1988. Effect of temperature, water activity and other toxigenic mold species on growth of Aspergillus flavus and aflatoxin production on corn, pinto beans and soybeans. J. Food Prot., 51: 361-363.

Yazdani D, MA Zainal Abidin, YH Tan and S Kamaruzaman, 2010. Evaluation of the detection techniques of toxigenic Aspergillus isolates. Afr. J. Biotechnol., 9: 7654-7659.

Zeinab HK, IH Nagwa and HAmra, 1992. Effect of incubation time, temperature and substrate on growth and aflatoxin production. Intl. Biodeterior. Biodeg., 30: 17-27. 